On the way out he chose war, dashed the Emperor's damned amphorae with a short sword.

-She should have come on heavy, breathing like slaves-he said, considering her big Nile dugs, her rivened ass.

Tony knew

that war is a green girl always to fall back on, to barely survive her thrashing, her inexperience with tongues (Octavian's gift, snaking down the steps like a purple robe to lie in).

He knew that foreplay's the thing to catch an aging queen if you can end it.

\title{
RAMSES ADAMANT
}

\author{
Ramses said her verse \\ was divorced from her person, though \\ she breathed it like a camel. \\ Her body works its hip on the lectern; \\ her lower lip is hot \\ and her asp eyes \\ seek the faces before her \\ for one more oasis.
}

